\title{
Science Teachers' and Continuous Assessment Implementation in Secondary Schools: Competence and Effects
}

\author{
${ }^{1}$ Marcus, Abiye Clement, ${ }^{2}$ Joseph, Endurance Ayibatonye \\ ${ }^{I}$ Department of Chemistry ${ }^{2}$ Department of Integrated Science, Ignatius Ajuru University of Education \\ Rumuolumeni, Port Harcourt, Rivers State
}

\begin{abstract}
The paper investigated the causes of the science teachers' indifference to the implementation of Continuous Assessment in Secondary Schools in Rivers State. The population of the study was the whole science teachers teaching in the Secondary Schools. From the population a sample of 200 science teachers were selected through a stratified random sampling technique. Three research question and two null hypotheses were formulated to guide the study. The instruments - the Teacher Continuous Assessment Attitude Rating Scale (TCAARS) was used to generate data. The instrument was validated and its reliability was tested using Kudar Richardson 20 formula $r=0.76$.

The data collected were analyzed; using simple percentage to answer the research questions while Analysis of Variance (ANOVA) was used to test the null hypotheses. From results analyzed, it was found that: (1) Many science teachers are not professionally qualified and as such lack the skills to construct and administer CA test in Secondary School (2) Large student population or classes (3) Lack of motivation (4) Lack of facilities for record keeping (5) Attitude and influence of parents and school administrators are some of the causes for the teacher indifference in CA implementation. Based on these some recommendations were proffered.
\end{abstract}

Key words: Science Teacher, Continuous Assessment, Implementation, Competence, effects.

\section{Introduction}

The main reason a teacher plans and delivers instruction is to aid the student to lean. But the question is, how does the teacher know that learning has taken place? How can it be ascertained what the student knows and can do, as result of having gone through the lesson or course? How does the teacher knows if the methods and materials used are effective? What evidence does the teacher gives to parents to convince them that the money being spent on their children's education is not being wasted.

To answer these questions among others, educational measurement experts and policy makers have come up with the concept of "Assessment" as a relevant tool.

Assessment is such an important part of education that, there have been many debates about which forms of assessment are best and which ones actually show how much student know.

The word "assess" according to Murphy (1975) means "to sit beside" or to assist the judge". Following up from this, United Nations Economics Commission for Africa (UNECA) (1985) held that it therefore seems appropriate in evaluation studies to limit the term assessment to the process of gathering the data and fashioning them to an interpretable form: judgments (evaluation) can be made on the bases of assessment." "To sit beside" according to (James, 1994) cited in Marcus (2008) conceptually, assessment involves sitting beside a growing child to observe, document, and describe qualitatively and quantitatively his cognitive, affective, and psycho motive behaviour and using the result as feedback to ensure valid identification of potentials as well as maximize desirable growth and development on which termed will later be made (Nenty, 1997a).

Several operational definitions have been advanced for "assessment (Wood, 1984; Izard, 1992 \& Messick, 1994). But fundamentally as it applies to education, it is anything done to find out what knowledge, skills, habits, attitudes, practices or generally what behaviour a learner has or does not have, acquire or develop, before during and at the end of an instruction, a period of instruction or course of study (Nenty, 1997b).

For a teacher to ensure desirable changes in learners' behaviour by the end of a lesson, quarter or year, there has to be a way of also ensuring changes at each step of the process that adds up to the observable terminal desirable changes, that is done as a means of determining the appropriate next step to take in the process, where in the process something should be done to encourage and maximize learning, and as a means of taking stock of observed progress or non-progress for classroom decisions. All these involve assessment. In that case, learning or changes in behaviour is continuous, progressive and cumulative. It does not take place only at the end of a term or year, but during each minute, if possible, of every lesson. Hence for an effective human development effort, a valid attempt to assess the extent to which learning has taken place should be continuous, progressive and cumulative (Nenty, 1991). 
From the foregoing a federal committee headed by Professor Yoloye on continuous assessment described traditional assessment method as "a type which is usually external, or internally administered and which relies very heavily on testing or examining towards the tail end of an educational programme and takes account of mostly knowledge of students" (Odelola, 2005). Thus in essence, this method was generally based on the result of an end of years examination which was used for making decisions on the student. Thus, the need for a new system of assessment and evaluation was strongly advocated. A more valid and reliable method of evaluation was the continuous assessment which was introduced in Nigeria school system in 1985. Among its numerous advantages over the traditional one-short examination were the facts that it is systematic, objective, comprehensive and Guidance-oriented.

Data collected through evaluation are obtained from a wide range of sources at weekly, fortnightly termly and are drawn from the three main domains of cognitive, affective and psychomotor. Thus continuous assessment has been defined as a method of determining the final grade of learner over a period of time through a series of periodic assessments including test and non-test measures.

The Federal Ministry of Education, Science and Technology handbook on continuous assessment (1985) defines continuous assessment as a mechanism whereby the final grading of a student in the cognitive, affective and psychomotor domains of behaviour takes account in a systematic way of all as the learners performance during a given period of school.

While Yoloye (2009) defines continuous assessment as a method of evaluating the progress and achievement of students in educational institutions, its aim is to get the true possible picture of each student's ability, at the same time helping each student to develop his/her abilities to the fullest.

Considering the concept further, Okonkwo (2002) defines continuous assessment as a method of evaluation in which learners achievement in the cognitive, affective and psychomotor domains from the moment they become learners until the end of it are determined using scores obtained from various instruments and techniques such as test, projects, rating scale, checklist, observation, interviews and other possible techniques.

Obe, (1980) defines continuous assessment as "the appraisal techniques which systematically cover all the students performance in class tests, home assignment, projects and other school activity during a given school period such as term, year or entire duration of the course.

Continuous assessment is a classroom strategy implemented by teachers to ascertain the knowledge, understanding and skills attained by learners. Airasian (1991) describes as an assessment approach which should depict the full range of sources and methods teachers use together, interpret and synthesize information about learners, plan and monitor instruction and establish a viable classroom culture. Falayajo (1986) describes it as an assessment of learners progress. According to him, it is mechanism whereby the final grading of the learners in the cognitive, affective and psychomotor domains of learning systematically takes account of all their performances during a given period of schooling. He further stressed that assessment in cognitive domain is associated with the process of knowledge and understanding, the affective domain applies to characteristics such as attitudes, motives, interest and other personality traits. Assessment in psychomotor domain, he further explained, involves assessing the learner's ability to use his or hands. From the definition so far X-rayed one could infer that continuous assessment is an approach which involves the use of a variety of assessment instructions, in assessing various components of learning, not only the thinking process, but including behaviour personality traits and manual dexterity. It takes place over a period of time. Such an approach is viewed to be more holistic, representing the learner in his/her entirety. It will begin with decisions that the teachers on the first day of school and end with the decision that the teacher and administration make on learners regarding end of year grading and promotion. The alternative to the traditional one short examination system "continuous assessment" was welcomed with enthusiasm, however, its implementation has been the bane of the success of the scheme. Teachers (The implementers) are required to implement the Continuous Assessment at all levels of education in Nigeria. However, the contrary has been the case because teachers have not fully embraced the rudiment of Continuous Assessment, Peters (1992) said Continuous Assessment implementation in secondary schools and condemn the emphasis of the characteristics of Continuous Assessment as comprehensive that is it obtainable only when the learners are measured in the cognitive affective and psychomotor domain.

Nenty (1991) posited that very low level of, or in most cases complete lack of teacher's competence in assessment among others mentioned inhibit effective assessment. The teacher is the major implementer of the Continuous Assessment programme in the classroom. However, in reviewing the current practices at the various levels of our educational system, and the attitude of the teacher in particular, one can without prejudice argue that the teacher's seminar is generally apathetic to its implement. The above assertion therefore has been the reason for this study. 


\section{Methodology}

To be able to identify the ineptitude of science teachers in the implementation of Continuous Assessment. The survey design strategy was adopted. The population of the study consisted of all the secondary school science teachers in the Rivers East Senatorial District from which a sample of 200 participants were selected through a stratified random sampling techniques: The entire district was divided into two strata, urban and rural from which it was further stratified to male and female. The simple random technique was employed at this stage to select 30 teachers (male and female) from each of the selected Secondary Schools. The data for the study was generated from a self development instrument: "Teachers Continuous Assessment Attitude Rating Scale" (TCAAARS): the instrument has three sections and 25 items prepared with a modified likert style of Strongly Agree (SA), Agree (A), Disagree (D) and Strongly Disagreed (SD). The instrument was validated by Professional with requisite knowledge on test and measurement. It reliability was tested using the Kudar Richardson 20 - Formular $(\mathrm{r}=0.76)$. The instrument were distributed to the respondents by the aid of research assistants at each school to the 200 sampled participants. However, only 180 of the instruments were returned. The data generated was analysed. The null hypotheses were tested using the analysis of variance (ANOVA).

\section{Research Questions:}

The following research questions were raised to guide the study.

Research Question 1: What are the perceived problems that affect Science Teachers implementation of Continuous Assessment in Secondary Schools?

Research Question 2: How competent are the Science Teachers in the implementation of Continuous Assessment in Secondary Schools?

Research Question 3: What are the factors that could motivate and promote the implementation of Continuous Assessment in Science Teachers.

\section{Hypotheses}

$\mathbf{H}_{0}$ : There is no significant difference in the teachers competence and Continuous Assessment implementation in Secondary Schools .

$\mathbf{H}_{02}$ : There is no significant difference in the gender and Continuous Assessment implementation.

Results

Research Question 1: What are the perceived problems that affect Science Teachers implementation of Continuous Assessment in Secondary School?

Table 1: Perceived Problems of Teachers not implementing Continuous Assessment in Secondary

\begin{tabular}{|c|c|c|c|c|c|c|}
\hline \multicolumn{7}{|c|}{ Schools? } \\
\hline S/NO & VARIABLES & NO & SA & $\mathbf{A}$ & D & SD \\
\hline 1. & $\begin{array}{l}\text { Population of Students may affect teachers' } \\
\text { motivation for assessment. }\end{array}$ & 180 & $\begin{array}{c}60 \\
33.3 \% \% \\
\end{array}$ & $\begin{array}{c}40 \\
22.2 \% \\
\end{array}$ & $\begin{array}{c}30 \\
16.66 \% \\
\end{array}$ & $\begin{array}{c}50 \\
27.7 \% \\
\end{array}$ \\
\hline 2. & $\begin{array}{l}\text { Time consumed and energy sapped in CA } \\
\text { implementation is considered a very serious } \\
\text { problem. }\end{array}$ & 180 & $\begin{array}{c}66 \\
36.6 \%\end{array}$ & $\begin{array}{c}48 \\
26.6 \%\end{array}$ & $\begin{array}{c}20 \\
11.1 \%\end{array}$ & $\begin{array}{c}46 \\
25.5 \%\end{array}$ \\
\hline 3. & $\begin{array}{l}\text { Teachers complain that CA is too frequent } \\
\text { because of the students' population. }\end{array}$ & 180 & $\begin{array}{c}30 \\
16.6 \% \\
\end{array}$ & $\begin{array}{c}38 \\
21.1 \% \\
\end{array}$ & $\begin{array}{c}42 \\
23.3 \% \\
\end{array}$ & $\begin{array}{c}70 \\
38.8 \% \\
\end{array}$ \\
\hline 4. & $\begin{array}{l}\text { Statistics involved cause many teachers to } \\
\text { shudder and feel bored due to large } \\
\text { population of classes }\end{array}$ & 180 & $\begin{array}{c}30 \\
16.6 \%\end{array}$ & $\begin{array}{c}38 \\
21.1 \%\end{array}$ & $\begin{array}{c}42 \\
23.3 \%\end{array}$ & $\begin{array}{c}70 \\
38.8 \%\end{array}$ \\
\hline
\end{tabular}

From Table 1 above, four major factors or variables were identified as causes of Science Teachers indifference in the implementation of continuous assessment in secondary schools in the area. Accordingly, the table showed that population of the students was one of the perceived and major cause. Out of 200 respondents $100(55.3 \%)$ agreed to the above fact. The second factor was that, the process consumes so much time and sapped energy $101.14(63.2 \%)$ of the respondents considered that as one factor that has impeded the proper implementation of continuous assessment in secondary schools. In the same vein, 100 respondents $(55.5 \%)$ saw the process of assessing the learners as too frequent and cumbersome especially in large population, thus results to the indifference in the implementation. Finally, out of the total respondent $62.3 \%$ said their problem was the issue of serious statistical calculation which is involve in the steps of making the continuous assessment scores valid in which a lot of the teachers at this level did not have enough expertise.

Research Question 2: How competent are the teachers in the implementation of continuous assessment in secondary schools. 
Science Teachers' and Continuous Assessment Implementation in Secondary Schools: .....

Table 2: Competency of teachers in implementation of continuous assessment.

\begin{tabular}{|c|c|c|c|c|c|c|}
\hline S/NO & VARIABLES & NO & SA & $\mathbf{A}$ & D & SD \\
\hline 1. & $\begin{array}{l}\text { All teaches receive Continuous Assessment } \\
\text { orientation at first appointment. }\end{array}$ & 180 & $\begin{array}{c}50 \\
27.7 \%\end{array}$ & $\begin{array}{c}30 \\
16.66 \%\end{array}$ & $\begin{array}{c}60 \\
33.3 \%\end{array}$ & $\begin{array}{c}40 \\
22.2 \%\end{array}$ \\
\hline 2. & $\begin{array}{l}\text { The average teacher is proficient in } \\
\text { measurement and evaluation. }\end{array}$ & 180 & $\begin{array}{c}60 \\
33.3 \%\end{array}$ & $\begin{array}{c}65 \\
36.1 \%\end{array}$ & $\begin{array}{c}20 \\
16.66 \%\end{array}$ & $\begin{array}{c}25 \\
13.8 \%\end{array}$ \\
\hline 3. & $\begin{array}{l}\text { Most teachers do not understand the concept } \\
\text { of Continuous Assessment. }\end{array}$ & 180 & $\begin{array}{c}70 \\
38.9 \%\end{array}$ & $\begin{array}{c}60 \\
33.3 \%\end{array}$ & $\begin{array}{c}25 \\
13.8 \%\end{array}$ & $\begin{array}{c}25 \\
13.8 \%\end{array}$ \\
\hline 4. & $\begin{array}{l}\text { Teachers who implement CA do not have } \\
\text { much education in CA during the Education } \\
\text { process }\end{array}$ & 180 & $\begin{array}{c}80 \\
44.5 \%\end{array}$ & $\begin{array}{c}60 \\
33.3 \%\end{array}$ & $\begin{array}{c}20 \\
11.1 \%\end{array}$ & $\begin{array}{c}20 \\
11.1 \%\end{array}$ \\
\hline
\end{tabular}

In Table 2 above it is obvious that some teachers are not competent enough to fully implement continuous assessment $44.3 \%$ revealed to have received orientation at first appointment while majority of the teachers $55.7 \%$ disagreed to have received any orientation or training and so are deficient in the systematic manner of Continuous Assessment processes. They agreed to have competent or proficient knowledge in measurement and evaluation $69.4 \%$ it is disharmonizing that $71.1 \%$ do not know much about the concept of continuous assessment and its principle. This imposes difficulty in the implementation of continuous assessment. Teachers who implement continuous assessment also show that they do not have much experiences in their education process as revealed by the table above, $80.5 \%$ of the respondents agreed that they do not have requisite experience. The table finally showcased that $77.8 \%$ respondents have not been exposed to conferences and workshops or any form of in training on how Continuous Assessment would be implemented.

Research Question 3: What are the factors that could motivate the implementation of Continuous Assessment in Secondary School?

Table 3: Motivations for implementation of Continuous Assessment in Secondary Schools.

\begin{tabular}{|c|c|c|c|c|c|c|}
\hline S/NO & VARIABLES & NO & $\mathbf{S A}$ & $\mathbf{A}$ & SD & D \\
\hline 1. & CA is very useful and should be encouraged. & 180 & 66 & 40 & 15 & 25 \\
\hline 2. & $\begin{array}{l}\text { Its usefulness is being met through the } \\
\text { improvement of the teachers instructional } \\
\text { techniques. }\end{array}$ & 180 & $\begin{array}{c}70 \\
38.92 \%\end{array}$ & $\begin{array}{c}72 \\
40.0 \%\end{array}$ & $\begin{array}{c}20 \\
11.1 \%\end{array}$ & $\begin{array}{c}18 \\
10.0 \%\end{array}$ \\
\hline 3. & $\begin{array}{l}\text { Its usefulness is being met in strengthening } \\
\text { the teachers' professional positions. }\end{array}$ & 180 & $\begin{array}{c}50 \\
27.7 \% \\
\end{array}$ & $\begin{array}{c}30 \\
16.6 \%\end{array}$ & $\begin{array}{c}40 \\
22.2 \%\end{array}$ & $\begin{array}{c}60 \\
33.3 \% \\
\end{array}$ \\
\hline 4. & $\begin{array}{l}\text { Supervision of CA in secondary schools is } \\
\text { adequate. }\end{array}$ & 180 & 30 & 30 & 50 & 70 \\
\hline 5. & $\begin{array}{l}\text { Supervision of CA implementation is } \\
\text { necessary }\end{array}$ & 180 & $\begin{array}{c}70 \\
38.9 \% \\
\end{array}$ & $\begin{array}{c}50 \\
27.1 \%\end{array}$ & $\begin{array}{c}40 \\
22.2 \%\end{array}$ & $\begin{array}{c}20 \\
11.1 \%\end{array}$ \\
\hline 6. & $\begin{array}{l}\text { Involvement of Parents, school authorities, } \\
\text { and government in CA supervision is very } \\
\text { adequate. }\end{array}$ & 180 & $\begin{array}{c}30 \\
16.6 \%\end{array}$ & $\begin{array}{c}20 \\
11.1 \%\end{array}$ & $\begin{array}{c}70 \\
38.8 \%\end{array}$ & $\begin{array}{c}60 \\
33.3 \%\end{array}$ \\
\hline
\end{tabular}

From the table above $58.8 \%$ sees Continuous Assessment very useful and should be encourage. This view they say is a enough motivation to strife hard to Continuous Assessment implementation compliance. $78.9 \%$ saw the usefulness of Continuous Assessment as enough motivating factor for which teachers should be motivated for its thorough implementation. The table further revealed that involvement of parents, school authorities and government is not adequate so teachers being the cheap implementers of Continuous Assessment should be motivated in the exercise to making sure that Continuous Assessment is well implemented.

$\mathbf{H}_{\mathbf{0 1}}$ : $\quad$ There is no significant difference in the implementation of Continuous Assessment in secondary school based on Teachers' competence.

Table 4: Analysis of Variance on the Teachers' Competence and Continuous Assessment Implementation

\begin{tabular}{|l|c|c|c|c|c|}
\hline \multicolumn{1}{|c|}{ Source of Variation } & Sum of Sq. & df & Mean sq & $\begin{array}{c}\text { Observed F } \\
\text { Value }\end{array}$ & $\begin{array}{c}\text { Expected F } \\
\text { Value }\end{array}$ \\
\hline Between groups & 39442.19 & 3 & 5767.87 & \multirow{2}{*}{3.03} & 24.03 \\
\hline $\begin{array}{l}\text { Within groups (Error) } \\
\text { Total }\end{array}$ & 2879.75 & 12 & 239.98 & & \\
\hline
\end{tabular}

The calculated F Value (3.03) from the above table is lower than the expected F. Value (24. P3) at 0.05 level of significance. This therefore, shows that teachers' competence may be a direct function of the implementation of Continuous Assessment IN Secondary Schools. The null hypothesis was therefore not accepted, that is the Teachers' competence is one of the overt reasons why science teachers are indifferent in Continuous Assessment implementation.

$\mathbf{H}_{\mathbf{0 2}}$ : There is no significant difference in gender and implementation of CA in secondary schools. 
Science Teachers' and Continuous Assessment Implementation in Secondary Schools: ......

Table 5: Analysis of Variance on Gender and Implementation of CA in Secondary Schools.

\begin{tabular}{|l|c|c|c|c|c|}
\hline \multicolumn{1}{|c|}{ Source of Variation } & Sum of Sq. & Df & Mean sq & $\begin{array}{c}\text { Observed F } \\
\text { Value }\end{array}$ & $\begin{array}{c}\text { Expected F } \\
\text { Value }\end{array}$ \\
\hline Between groups & 15558.73 & 3 & 46676.18 & & \\
\cline { 1 - 4 } Within groups (Error) & 982.27 & 12 & 25 & \multirow{2}{*}{15.83} & 31.49 \\
Total & & 15 & & & \\
\hline
\end{tabular}

\section{Discussion Of Findings}

The study deals with the factors responsible for Science Teachers' indifference to the implementation of continuous assessment in Secondary Schools. The study revealed that the major problem or factor causing the indifference is that the Science teachers which are the main implementers of Continuous Assessment lack the basic skills and rudimentary training in test constriction and administration. This agrees with the finding of (Alansa, 2003). The skills a teacher should have to be able to implement Continuous Assessment at this level of education include:

$\checkmark$ Science Teachers should be able to state measurable instructional objectives for each lesson.

$\checkmark$ Teacher should be able to conduct audience analysis in other to determine the learning styles, study habits of learners and so on.

Since majority of the teachers in the public schools do not possess the required skills, it seems so impossible for the implementation of continuous assessment in the school.

Another factor causing the indifference is seen in the difficulty of teachers to measure the learner's affective attributes such as interest, attitude, motives, values and other personality traits as shown in Table 4 above. Such characteristics could be as important as others associated with intelligence. They could assist the teachers and administration in understanding the learner better, both in the process of education and in the practical activities of everyday life. They also provide clues about the interest patterns of learners which could be used in their placement into schools of higher learning and for employment purpose (Obemeata, 1988).

It is believed that if such skills are acquired by teachers and continuous assessment is fully implemented by teachers, anti-social behaviours such as truancy, lying, cheating, pilfering and poor attitude to work and school could be corrected.

Significant in continuous assessment implementation is motivation which the study revealed that teachers are not motivated in any way (Table 3 above). This finding agrees with Peterson (1995), who reported that much of teachers work is carried out in self contained classrooms that isolate them from the support of their colleagues. Because of this organizational structure, teachers are difficult to supervise, do not received regular feedback from others and often find it hard to collaborate (Johnson, 1986) also agrees with the facts and said that for continuous assessment implementation to be result oriented, teachers' motivation measure should be based on the three principles:

$\checkmark \quad$ Expectancy Principle: Individuals are more likely to strive in their work if there is an anticipated reward that they value.

$\checkmark \quad$ Equity Principle: Individuals are dissatisfied if they are not justly compensated for their efforts and accomplishments.

$\checkmark \quad$ Job Enrichment Principle: Workers are more productive when their work is varied and challenging. He further said that current school environments are a reward scarce setting for professional work and often seem to work against teachers' best efforts to grow professionally and improve students. The research of (Alausa, 2003) also agrees this assertions, that an unmotivated teacher may have the tendency to merely "cook up" scores in the name of continuous assessment. Thus teachers should be encouraged to form favourable attitudes towards the practice.

Finally, learners', records have to be adequately and meticulously kept over a long period of time. They should be properly stored and easily retrievable, but since facilities like filling cabinets, shelves, file jacket are dearth in schools, teacher feel record keeping is a waste of effort and show indifference to recording keeping and implementation of continuous assessment.

\section{Conclusion}

Teachers are the main players on the implementation of continuous assessment in schools. For successful implementation of continuous assessment the onus lies wholly on the classroom teacher. The study revealed that teachers engaged in the public schools in the area under study are indifferent to implementing continuous assessment in the various schools. The causes of indifference in continuous assessment implementation are embedded in the following factors:

1. A lot of the science teachers in the secondary schools are not professionals and so do not possess the rudimentary skills to construct and administer continuous assessment test in the school. 
2. The students' population is another factor, some of the schools are over populated and such makes the teacher dread in implementing continuous assessment properly and adequately. It will make the teacher give more tests and do more marking this makes the teacher to become disinterested in operating the system. Scores are rather "cooked up" by most teachers.

3. Lack of adequate motivation, good working environment are seen to be scarce and so teachers feel that it is irrelevant to die in ventures that never can contribute to their well being.

4. Lack of facilities such as filling cabinet, file jackets, shelves contribute to teachers' indifference or general apathy to continuous assessment implementation.

5. Factors such as parents' influence, principals, promoting students massively defies the rationale for continuous assessment. Teachers therefore, feel that after spending time to judiciously and religiously implement continuous assessment principals, parents and government abuse it by promoting students at the expense of the thorough jobs that have been done. So teachers fell that, there is no need to die in undoubtful ventures.

\section{Recommendations}

Based on the finding of the research, the following recommendations are made:

1. Since continuous assessment is part of the educational system, science teachers who are the main players should be trained professionally to execute and properly implement continuous assessment as spelt out in the National Policy of Educators.

2. Government should create an enabling and motivating environment for the teachers for better educational productivity.

3. Regular workshops and seminars including in-service training be given to the teachers to update their knowledge on continuous assessment implementation.

4. Principals and school administrators should provide adequate record keeping system for continuous assessment so that scores can be stored for a long time and would be easily retrievable when needed.

\section{References}

[1]. Airasian, P. W. (1991). Classroom Assessment: New York. McGraw-Hill.

[2]. Alausa, Y. A. (2003). Continuous Assessment in Our Schools, Advantages and Problems. Southern African Conference on Continuous Assessment.

[3]. Falayajo, W. (1986). Philosophy and Theory of Continuous Assessment. A Paper Presented at a Workshop for Inspectors of Education in Ondo State Nigeria.

[4]. Johnson, S. M. (1986). "Incentives for Teachers: What Motivates, What Matters". Educational Administration Quarterly, 22 (3) 54-76.

[5]. Marcus, A. C. (2008). Factors Responsible for Teachers Indifference to the Implementation of Continuous Assessment in Selected Public Schools in Rivers State. Unpublished Dissertation University of Science and Technology, Port Harcourt.

[6]. Messick, S. (1994). The interplay of evidence and consequences on the validation of performance assessment: Educational Researchers. 23(2), 13-23.

[7]. Murphy, R. T. (1975). Assessment. In S. B. Anderson, S. Ball \& R. T. Murphy (Ed). Encyclopedia of Educational Evaluation. San Francisco: Jossey - Bass Publishers.

[8]. Nenty H. J. (1997a). Basic Assessment Skills for Classroom Teachers. Unpublished Manuscript. Institute of Education, National University of Lesotho, Lesotto.

[9]. Nenty H. J. (1997b). Assessing Learning and Managing Examinations. A Paper Presented in Management Training Workshop of Primary School Principal at National University of Lesotto, pp 13-23.

[10]. Nenty, H. J. (1985). Fundamentals of Educational Measurement and Evaluation: Unpublished Manuscript: University of Calabar, Nigeria.

[11]. Nenty, H. J. (1996). Advanus in Test Evaluation. An Invited Paper Presented at a Conference on Management Assessment Problems in Nigeria at Ikeja, Lagos Nigeria.

[12]. Obe, E. O. (1983). A Survey of Attitudes of Some Lagos Secondary School Teachers Towards Continuous Assessment. JORIC $1(1), 9-16$.

[13]. Obemeata, J. O. (1988). Non-Cognitive Assessment in Educational Evaluation Lecture notes at the Institute of Education, University of Ibadan, Nigeria.

[14]. Odelola, J. A. (2005) The Relevance of Continuous Assessment in Improving the Academic Achievement of Student. Journal of Pedagogy and Educational Development. 11(1) $58-64$.

[15]. Ojennde, D. \& Okonkwo, S. C. (N. D). National Examinational Council. Minna Niger State.

[16]. Okonkwo, S. C. (2002). An Evaluation of Continuous Assessment Standards and Practices in Nigeria Secondary Schools. Journal of Quality Education. 6, 125-136.

[17]. Peterson, K. D. (1995). Teacher Education. A Comprehensive Guide to New Directions and practices. Thousand Oaks, C. A. Corwin Press.

[18]. United Nations Economic Commission for Africa (UNECA) (1985). Trends and Issues in Africa Education (Educational Mineograph No. 3) Addia Ababa.

[19]. Wood, R. (1984). Assessment has too many meanings and the one I think we want isn't clear enough yet. Educational Measurement: Issues and Practices. 3(4)5-7.

[20]. Yoloye, A. E. (1984). Continuous Assessment: A Simple guide for teacher Casell, London. 